\title{
THE INFLUENCE OF BOARD CHARACTERISTICS ON THE FREQUENCY OF 10-K INVESTIGATIONS OF FIRMS IN THE FINANCIAL SERVICES SECTOR
}

\author{
Mel E. Schnake \\ William B. Fredenberger \\ Robert J. Williams \\ Valdosta State University \\ Valdosta, GA
}

\begin{abstract}
This study examined the possible impact of board member composition (number of outside directors), board tenure, board size, and the number of other boards on which directors serve, on the number of investigations and/or legal proceedings brought against the sample firms by various individuals, groups, and federal and state agencies. A sample of 180 firms were selected for study from the financial services sector of the economy for the years 1998-2002.

The results suggest that, contrary to theory, neither the proportion of outside directors or board size had a significant affect on the number of investigations brought against the sample firms. Further, as predicted, the results revealed a significant and negative link between board tenure and the number of $10 \mathrm{~K}$ investigations, and a significant and positive relationship between the number of other boards served on by directors and the number of investigations. Although contraty to theory, this last finding offers some evidence that directors who serve on several other boards may become too distracted to properly monitor their firms.
\end{abstract}

Corporate governance continues to be an area of interest to researchers, stakeholders, and the general public (Sonnefeld, 2004). The influence of board characteristics on firm financial performance has been heavily researched over the past few years. Such board characteristics as board size, board tenure, number of inside and outside directors, number of female board members, and number of other boards on which members serve have been related to a variety of firm performance measures. Dalton, Daily, Ellstrand and Johnson (1998) and Dalton, Daily, Johnson and Ellstrand (1999) performed a meta-analysis to summarize the often-conflicting research results in this area and concluded that there is little evidence that board characteristics influence firm financial performance.

Researchers have also begun to examine the influence of board characteristics on aspects of firm performance beyond financial performance. It is suggested that there may be incompatible interests between managers and stakeholders which may adversely affect the social performance of an organization (Simerly, 1995). One view is that the primary responsibility of a business is to maximize 
profit. This may give social performance and responsibility a back seat, or perhaps even divert resources away from social performance. The stakeholder view is that businesses are given legitimacy by society and, therefore, have a responsibility to behave in a socially responsible manner (Freeman, 1984). An integrative view is that social responsibility may actually contribute to business success (Werner, 1992).

Wood (1991 a, 1991b) has described "corporate social performance" as consisting of three components. The first component, corporate social performance, has to do with firm public responsibility and legitimacy within society. The second component is corporate social responsiveness and includes environmental assessment and stakeholder management. The third component consists of the outcomes of firm behovior and includes social impacts, social programs, and social policies. Obviously, corporate social performance can be measured in a variety of ways and this has lead to conflicting research results to date (Stanwick \& Stanwick, 1998).

One dimension of firm behavior related to corporate social performance is the legality of a firm's actions. Kesner and Johnson (1990) examined the relationship between board characteristics and shareholder lawsuits in the state of Deleware. They found a positive relationship between the proportion of inside directors and the likelihood of a firm's board of directors being sued by a shareholder for failure to maintain their fiduciary responsibilities. They also tested for the possibility that shareholders tend to file more lawsuits when firm performance is poor, by controlling for both return on assets and return on equity, and found no support for this hypothesis. In contrast, in a study of Fortune 500 firms, Kesner, Victor and Lamont (1986) found no relationship between the proportion of outsiders on boards of directors and illegal acts (consent and litigation decrees entered in federal and state courts for cases involving possible violations of antitrust laws and the Federal Trade Commission Act). Thus, the issue of whether the proportion of outsiders reduces firm illegal acts and/or lawsuits against the firm and/or board of directors is far from settled.

\section{Outside Directors}

There are three primary reasons for including outsiders on a firm's board of directors (Vance, 1983). First, outsiders may increase the breadth of experience and knowledge of the board enabling it to make better decisions. In addition, outsiders may also have contacts which enable them to secure scarce resources for the firms they represent. Finally, outsiders may be more independent from the CEO and/or top management team and, therefore, better able to protect shareholder interests.

Current trends in corporate governance have resulted in an increase in the proportion of outsiders on many firm's boards. While Heidrick and Struggles (1986) observed an outsider ratio of $75 \%$ in 1985, this proportion had increased to $81 \%$ by 1999 (Wheelen \& Hunger, 2004). This trend toward more outsiders has resulted from the growing influence of institutional investors such as CalPERS, 
TIAA-CREF, various pension funds, mutual funds, and insurance companies who are putting increased pressure on firms to improve performance (Wheelen \& Hunger, 2004). In November, 2003, the Securities and Exchange Commission approved new listing standards that apply to companies listed on the New York Stock Exchange and NASDAQ. These standards require that a majority of a listed firm's board be composed of independent (i.e., outside) directors.

Wang and Dewhirst (1992) found that outside directors are very committed to representing various stakeholders, beyond just the stockholders. As a result they tend to be sensitive to environmental issues, women and minorities, and employees. They are also more likely to be knowledgeable about issues facing the firm and comply with legal requirements in order to avoid penalties and negative public relations (Johnson \& Greening, 1999).

\section{Board Tenure}

There are two competing hypotheses regarding the relationship between board tenure and firm performance (Vafeas, 2003). The expertise hypothesis suggests that longer tenure is related to board member experience, commitment, and competence. This may translate into greater financial and social performance of the firm. In contrast, the management friendliness hypothesis suggests that longer tenure is associated with a "management-friendly" board. Management friendly boards may lose their objectivity and independence resulting in lower financial and social performance. Vafeas (2003) found a positive relationship between outside director board tenure and their occupying a "management friendly" occupation as well as sitting on the firm's compensation committee. Board tenure on the compensation committee, in turn, was further associated with CEO compensation levels, thus providing some support for the management friendliness hypothesis.

In addition to becoming too management-friendly, other disadvantages may accompany long board tenure. Long board tenure may limit cognitive conflict among board members, and may restrict the number of views and opinions that are openly discussed and debated by the board (Daboub, Rasheed, Priem \& Gray, 1995; Lau \& Murnighan, 1998). Symptomatic of reduced cognitive conflict, long tenure has been associated with commitment to the organizational status quo and with group conformity (Finkelstein \& Hambrick, 1990; Hambrick \& Fukutomi, 1991; Hambrick \& Mason, 1984; Weirsema \& Bantel, 1992).

Long tenure may reduce information processing among members, as board members limit their information sources over time, and members may be more apt to anticipate the views of fellow board members over time (Finkelstein \& Hambrick, 1990; Katz, 1982; Michel \& Hambrick, 1992, Staw \& Ross, 1980). Long-tenured board members may lose their ability to recognize and respond to changing environmental conditions (Daboub, et al., 1995). Such heightened conservatism and reduced information processing might encourage "sloppy" management oversight, and may support an environment in which firm misbehavior is more likely to occur. As a result, long tenured board members may be 
slow to detect and react to certain legal violations committed within the firm. Based on this, we expect a positive relationship between board tenure and the number of $10 \mathrm{~K}$ investigations.

\section{Board Size}

The research evidence on the effects of board size on firm performance is equivocal. Resource dependence theory suggests that larger boards may enable the firm to more easily form critical environmental linkages and secure scarce resources (Pfeffer \& Salancik, 1978; Mintzberg, 1983; Goodstein, Gautam \& Boeker, 1994). In contrast, Jensen (1993) argues that large boards may function ineffectively and may be easier for a CEO to control. With increasing group size come problems such as social loafing (Kidwell \& Bennett, 1993), and decreased group cohesiveness (Lipton \& Lorsch, 1992).

On the other hand, Zahra and Pearce (1989) argue that larger boards may not be as susceptible to CEO domination as are smaller boards. A meta-analysis by Dalton, Dailey, Johnson and Ellstrand (1999) provide some evidence about this issue. They found a small, positive relationship between board size and frm financial performance. This relationship was moderated by firm size, such that the board size and firm financial performance relationship was stronger for small firms. While there is no specific research to guide us, board size may interact with other board characteristics to influence firm performance.

With respect to firm oversight, there is no consensus as to whether larger or smaller boards are better able to monitor the firm. Larger boards are generally more diverse and less cohesive than smaller boards. Such diversity among board members encourages conflict and debate, and results in the formation of a wide variety of decision alternatives (Dalton, et al., 1999; Johnson, Daily \& Ellstrand, 1996). A larger board possesses more specialized skills and opinions among its members than a smaller board, and is better equipped to obtain and process a great deal of information about the firm and its environment (Amason \& Sapienza, 1997). Having more members, a larger board should be better equipped to monitor the firm through the establishment of specialized oversight committees (Pearce \& Zahra, 1992; Zahra \& Pearce, 1989).

A large board serves to constrain the firm's top management team from exerting excessive political influence (Ocasio, 1994). Rival political coalitions are better able to emerge in larger boards, and serve to challenge the top management team and the political factions it has created (Ocasio, 1994; Pearce \& Zahra, 1992).

Some researchers take the opposing view, and argue that smaller boards may be better able to monitor the firm. They argue that larger, more heterogeneous boards serve a co-optive function by linking the firm with its environment and buffering the firm from environmental disturbances (Alexander, Fennel $\&$ Halpern, 1993; Chaganti, Mahajan \& Sharma, 1985). Such an outward view by the board may provide certain advantages, especially when it comes to firm survival. Nevertheless, it follows that some boards may be too outwardly 
focused, and less concerned about internal policy making and the internal control functions needed to adequately monitor the firm (Alexander, et al., 1993; Chaganti, et al., 1985). Smaller boards may encourage greater focus, more member participation and cohesiveness, less social loafing, and genuine debate among board members than larger boards (Firstenberg \& Malkiel, 1994; Lipton \& Lorsch, 1992).

When there is disagreement and fragmentation among board members, as is more common in larger boards, the top management team can gain relative advantage in power and influence through a number of political strategies, including coalition-building, selective channeling of information, and "dividing and conquering" (Alexander, et al., 1993). Smaller boards, therefore, may be less subject to manipulation by the top management team (Alexander, et al., 1993; Lipton \& Lorsch, 1992).

While both views regarding board size have merit, we were swayed by the dual advantages of larger boards, and the meta analysis by Dalton, et al. (1999). Specifically, larger boards possess more human assets needed to properly monitor the firm, and may be more inclined to create specialized subcommittees for this purpose. In addition, larger boards should provide more fertile ground for the emergence of rival political coalitions to challenge the firm's top management team. Based on this, we expect a negative relationship between board size and the number of $10 \mathrm{~K}$ investigations, after controlling for the effects of firm size.

\section{Number of Other Boards on Which Directors Serve}

There is some evidence that board interlocks may be associated with effective capital acquisition (Mizruchi \& Stearns, 1988; Stearns \& Mizruchi, 1993). Thus, a board whose directors also serve on several other boards may enable the firm to gain access to critical resources and vital information through these interlocking directorships (Zahra \& Pearce, 1989). Such information may enable a board to be more aware of potential legal liabilities and the importance of good social performance. Interlocked directors may be able to observe investigations and legal proceedings against other firms on whose boards they serve, and bring that information back to the remaining boards on which they serve, enabling these firms to take action to avoid similar proceedings. Therefore, we expect a negative relationship between the number of other boards on which members serve and the number of $10 \mathrm{~K}$ investigations.

\section{Firm Size}

While the issue may not be completely decided, a preponderance of the extant research literature suggests a positive relationship between organizational size and firm financial performance ( Dalton, Todor, Spendolini, Fielding \& Porter, 1980; Judge, 1994). Larger firms have greater capacity to meet demand, wider depth and variety of human resources, a wider variety of suppliers and customers, and greater slack resources (Kimberly, 1976). In terms of firm social performance, Spicer (1978) found firm size to be positively related to pollution control in the 
pulp and paper industry. Cochran (1985) found firm size was inversely related to the frequency of golden parachutes. Preston and Sapienza (1990) found firm size was positively related to perceptions of social responsibility.

While clearly not a settled issue, larger firms may be more concerned with their public image and, therefore, devote more effort and resources toward social performance. They may also, of course, have greater resources to expend on social performance. Dalton and Kesner (1983) suggest that larger firms are more complex and that size and complexity may cloud relationships between board composition and firm performance. Zahra and Pearce (1989) argue that directors of large, complex firms may find it more difficult to exert control over firm performance and/or the top management team. Several authors have suggested that boards may be able to exert greater influence in smaller firms (Eisenhardt \& Schoonhoven, 1990; Finkelstein \& Hambrick, 1990; Dailey \& Dalton, 1992; 1993). To isolate the relationships between board characteristics and the incidence of $10 \mathrm{~K}$ investigations, firm size was employed as a control variable in the current research.

\section{$10 \mathrm{~K}$ Investigations}

Researchers generally agree that corporate social performance (CSP) is multidimensional (Carroll, 1991; Griffin \& Mahon, 1997). Previous researchers have operationalized CSP variously as the firm's impact on the community in which it operates, impact on the environment, treatment of women and minorities, employee relations, and product quality (Johnson \& Greening, 1999). Johnson and Greening, (1999) collapse these aspects of CSP into two dimensions: a people dimension (community, women and minorities, and employee relations), and a product quality dimension (product quality and environment).

A relatively broad measure of possible firm misbehavior, which is one aspect of CSP, is the number of investigations reported in each firm's 10-K Reports. We use the term "investigations" because not all of these actions result in legal proceedings. Specifically, $10 \mathrm{~K}$ investigations involve those investigations and legal proceedings instituted by the U.S. Department of Justice, the Securities and Exchange Commission, the Environmental Protection Agency, the Federal Trade Commission, the Equal Employment Opportunity Commission, or similar agencies at the state level. If brought to fruition with sanctions against the firm, these proceedings could significantly impact the firm's long term financial position as well as the public's perception of the social responsiveness or legitimacy of the firm. These types of serious violations are the direct responsibility of the board to monitor and prevent, and may include investigations involving accounting fraud, product liability, environmental degradation, workplace discrimination, antitrust activity, and employee safety. Thus, $10 \mathrm{~K}$ investigations relate to both of Johnson and Greening's (1999) dimensions of corporate social performance. Investigations by the EEOC and OSHA relate to the people dimension, while investigations by the SEC, Department of Justice, and EPA relate to the product quality dimension. 
Based on previous research, the following research hypotheses are offered:

Hypothesis 1: The proportion of outsiders on boards of directors will be negatively related to the number of $10 \mathrm{~K}$ investigations, after controlling for the effects of organizational size.

Hypothesis 2: Higher board tenure will be positively related to the number of $10 \mathrm{~K}$ investigations, after controlling for the effects of organizational size.

Hypothesis 3: Larger board size will be negatively related to the number of $10 \mathrm{~K}$ investigations, after controlling for the effects of organizational size.

Hypothesis 4: The number of other boards on which directors of afirm serve will be negatively related to the number of $10 \mathrm{~K}$ investigations, after controlling for the effects of organizational size.

\section{Method}

\section{Sample Firms}

The financial services sector of the U.S. economy was selected for study. Beginning with all 1,337 firms in this sector listed with the SEC between 1998 and 2002, we eliminated all firms not on the New York Stock Exchange. Next we eliminated all firms that did not have at least three $10-\mathrm{Ks}$ during the five-year study period. This resulted in 192 firms drawn from the following industries within this sector; (1) consumer financial services, (2) accident and health insurance, (3) life insurance, (4) property and casualty insurance, (5) investment services, (6) money center banks, (7) regional banks, (8) savings banks, and (9) miscellaneous financial services. Some of these firms are holding companies with only 5 to 10 employees. After eliminating these by selecting only firms with 100 or more employees, 180 firms remained in the data set.

This study was limited to firms within a single sector so as to reduce any possible industry effects (e.g., different technologies, product life cycles, etc.). Given that financial services firms are highly regulated by various state and federal agencies, the potential impact of board characteristics on these firms should be of particular interest. We preferred that the sample firms have five (5) $10 \mathrm{~K}$ Reports (i.e., one each for the period 1998-2002), but we decided to accept firms that had at least three $10 \mathrm{~K}$ Reports that were available through our data source during the study period.

\section{Board Characteristics}

Board composition data were gathered from the Edgar database compiled by the Securities and Exchange Commission. The sample firms' $10-\mathrm{K}$ Reports and 
Def 14-A Reports for the years 1998-2002 were the sources of the data. We were able to obtain board data for each firm which included (1) average board size (total number of directors) during the study period, (2) the board composition--insiders versus outsiders, (3) the average tenure of each firm's board during the study period, and (4) the average number of other boards that each director served on during the study period. In addition, the average number of each firm's employees during the study period served as the measure of firm size, and was obtained from Hoover's Company Profiles. All of the following variables represent the average over the five year study period.

In determining whether a director was an insider or an outsider, we were keenly aware of the lack of independence and potential inadequacies in firm monitoring posed by, so called, "gray" directors (Ryan and Wiggins, 2004). Gray directors may be retired former directors or employees of the firm, or they may be family directors with family ties to the firm's founder and may hold large blocks of the firm's stock.. In addition, gray directors may work for other affiliated firms that are large suppliers of the firm, or other firms that may handle the insurance, legal, or consulting work for the firm.

While it is often difficult to identify gray directors, we did make a diligent effort to do so. In compiling the data, we opted to classify family directors, retired former directors and employees, and affiliated directors as insiders. While these directors were not technically insiders, their influence would, in all likelihood, exert the same level of independence as an insider.

\section{Investigations}

A measure of one aspect of corporate social performance, the number of investigations initiated against each firm, was obtained from the SEC Edgar database. A detailed description of these investigations, if any, are presented in Item 3 of each firm's $10 \mathrm{~K}$ Reports. The number of $10 \mathrm{~K}$ investigations was selected as a measure of firm social performance as these investigations reflect possible corporate misbehavior, and reflect how well firms are being monitored by their boards. Only those investigations conducted between 1998-2002 were included. The possible types of misbehavior for which firms are investigated are frequently very serious in nature, and involve legal proceedings beyond the firm's ordinary business activity.

In analyzing the $10 \mathrm{~K}$ reports, two raters were used to categorize the types and timing of the various investigations. In the vast majority of cases, the raters were in agreement as to the nature and time period in which the investigations were undertaken. In the few cases where agreement could not be reached, a third rater was used to settle the issue.

\section{Results}

Variable characteristics and a correlation matrix appear in Table 1. As shown in the table, the average number of $10 \mathrm{~K}$ investigations was significantly and posi- 
tively correlated with only the average number of employees (i.e., firm size), and the average number of boards on which board members serve, but significantly and negatively correlated with the average years of service of board members.

\section{Table 1}

\section{Variable Characteristics and a Correlation Matrix}

\begin{tabular}{lccccccccc}
\hline & Mean & $\begin{array}{l}\text { Std. } \\
\text { Dev. }\end{array}$ & $\mathbf{1}$ & $\mathbf{2}$ & $\mathbf{3}$ & $\mathbf{4}$ & $\mathbf{5}$ & $\mathbf{6}$ \\
\hline $\begin{array}{l}\text { 1. Proportion of } \\
\text { Outside Directors }\end{array}$ & .73 & .13 & 1.00 & $.30^{* *}$ & .14 & $-.15^{*}$ & $.26^{* *}$ & .06 \\
$\begin{array}{l}\text { 2. Average Total } \\
\text { No. of Directors }\end{array}$ & 11.89 & 4.10 & & 1.00 & $.34^{* *}$ & -.02 & .08 & .01 \\
$\begin{array}{l}\text { 3. Average No. } \\
\text { of Employees }\end{array}$ & $12,964.49$ & 26651.10 & & & 1.00 & -10 & $.44^{* *}$ & $.37^{* *}$ \\
$\begin{array}{l}\text { 4. Average Years } \\
\text { on Board of }\end{array}$ & & & & & & & & \\
$\begin{array}{l}\text { All Members } \\
\begin{array}{l}\text { 5. Average No. of } \\
\text { Boards On Which }\end{array}\end{array}$ & 8.57 & 3.92 & & & & 1.00 & $-.34^{* *}-.28^{* *}$ \\
$\begin{array}{l}\text { All Members Serve } \\
\text { 6. Average 10K }\end{array}$ & 1.82 & 1.13 & & & & & & 1.00 & $.41^{* *}$ \\
Investigations & 2.14 & 3.71 & & & & & & 1.00 \\
\hline
\end{tabular}

$\mathrm{N}=180 * \mathrm{p}<.05 * * \mathrm{p}<.01$

Stepwise regressions were performed to test hypothesized relationships among the variables (Cohen \& Cohen, 1983). Average number of employees (firm size) was entered on the first step of the regression analysis, followed by the four independent variables (board characteristics). A significant change in the R-squared value indicates that the independent variables contribute to explained variance in the number of $10 \mathrm{~K}$ investigations beyond the effect of firm size. Before performing this analysis we checked for significant interaction effects among the independent variables. All four-way, three-way, and two way interactions did not achieve traditional levels of statistical significance. Therefore, it was appropriate to interpret the main effects. Both main effects and the control variable (organizational size measured by number of employees) were statistically significant. These results are presented in Table 2. 
Table 2

Results of the Stepwise Regression Analysis of Board Characteristics on 10K Investigations

\begin{tabular}{lccc}
\hline & $\mathbf{R}^{2}$ & Change in $\mathbf{R}^{2}$ & Signif. \\
\hline Size & .14 & .14 & .00 \\
Years, Prop Out, Board Size, Other Bds & .25 & .11 & .00 \\
\hline
\end{tabular}

Size $=$ Firm Size (Average Number of Employees)

Prop Out $=$ Proportion of Outsiders

Board Size $=$ Average Total Number of Directors on Board

Other Bds $=$ Average Number of Boards on Which Directors Serve

Years $=$ Average Total Years of Service of Board Members

$10 \mathrm{~K}=$ Average Number of $10 \mathrm{~K}$ Investigations

To determine the relative contribution of independent and control variables to the explained variance in the number of $10 \mathrm{~K}$ investigations, beta coefficients were examined. These appear in Table 3.

Table 3

Standardized Beta Coefficients of Independent and Control Variables

\begin{tabular}{ll}
\hline Independent and Control Variables & Std. Beta \\
\hline Size & $.28^{* *}$ \\
Years & $-.17^{*}$ \\
BoardSize & -.09 \\
Other Bds & $.24^{* *}$ \\
Prop Out & -.04 \\
Model $\mathrm{R}^{2}$ & $.25^{* *}$ \\
\hline
\end{tabular}

$N=180 * p<.05 * * p<.01$

Size $=$ Firm Size (Average Number of Employees)

Prop Out $=$ Proporion of Outsiders

Board Size = Average Total Number of Directors on Board

Other Bds = Average Number of Boards on Which Directors Serve

Years = Average Total Years of Service of Board Members

$10 \mathrm{~K}=$ Average Number of $10 \mathrm{~K}$ Investigations

Firm size, as predicted, was positively and significantly related to the number of $10 \mathrm{~K}$ investigations. No support was found for hypotheses H1. The proportion of outsiders on boards of directors was not significantly related to the number 
of $10 \mathrm{~K}$ investigations, after controlling for the effects of firm size. Contrary to $\mathrm{H} 2$, board tenure was negatively related to the number of $10 \mathrm{~K}$ investigations, after controlling for the effects of firm size. Hypothesis $\mathrm{H} 3$ was not supported. Board size (total number of board members) was not significantly related to the number of $10 \mathrm{~K}$ investigations, after controlling for the effects of firm size, suggesting that larger boards may be better firm monitors than smaller boards. In contrast to hypothesis $\mathrm{H} 4$, the number of other boards on which directors serve was significantly and positively related to $10 \mathrm{~K}$ investigations, after controlling for the effects of organizational size. Taken together, these variables explained $25 \%$ of the variance in the number of $10 \mathrm{~K}$ investigations. Firm size alone explained slightly over one-half of this variance. The number of other boards on which members serve and board tenure explained the other half.

\section{Discussion}

In recent years, public confidence in corporations has been diminished in light of scandals such as Enron and Worldcom. This study has examined four specific board member characteristics and their potential influence on a board's ability to adequately monitor its firm.

Surprisingly, the results failed to support a significant link between either the proportion of outside directors or board size and the number of $10 \mathrm{~K}$ investigations instigated against the sample firms. Whether the proposed benefits of outside director independence is, in general, overstated, or whether the benefits of outsiders is less evident in financial services firms is unclear. At any rate, the inclusion of more outsiders on the sample firms' boards failed to reduce the number of investigations brought against the firms.

The growing influence that institutional investors have over boards to prompt them to appoint more outsiders might not produce the desired results for firms in this sector. These firms tend to be highly regulated by various regulatory agencies. Perhaps, the benefits of having more independent and objective outsiders might be more evident for firms in industries that lack such stringent oversight. Similar research in other industries is strongly recommended to determine whether the results of the current study are industry specific.

The notion that long board tenure tends to encourage board "staleness" and management-friendly behavior was not supported by the results. Among the sample firms, each board member served, on average, 8.6 years on his/her firm's board. While a measure of top management team tenure was beyond the scope of this study and was not included, the average level of board tenure may be considerably less than the average top management team tenure for the sample firms. Such a discrepancy, if it exists, might reduce the management-friendly orientation of the board. Or, perhaps, boards do not become "management-friendly" until much later in their tenures than the average observed in this study.

Our findings suggest that longer board tenure is associated with fewer $10 \mathrm{~K}$ investigations. Consistent with the "expertise hypothesis," perhaps the experience 
of board members results in members increased effectiveness in monitoring firm decisions and actions. Our findings are also inconsistent with the "management friendly hypothesis" which suggests that board members lose their objectivity with longer tenure.

The findings did not suggest that larger boards may be better monitors of the firm than smaller boards. Others have speculated that, consistent with resource dependence theory (Pfeffer \& Salancik, 1978), larger boards have more resources (human assets) available to monitor and guide the firm. From a political perspective, larger boards should provide more fertile ground for rival factions to emerge and challenge the top management team. Nevertheless, the benefits associated with larger boards would probably occur only over a range of board sizes - as boards become too large, too diverse, and hard to coordinate, these benefits would, in all likelihood, begin to diminish. Our results do not support this argument.

Although contrary to theory, the significant and positive link between the number of other boards served on by directors and $10 \mathrm{~K}$ investigations strongly supports the notion that directors may become distracted and too involved with the affairs of other firms to properly manage the affairs of the focal firms. This seems logical, given the limited time and energy of directors, as well as the possible different industry settings that directors may encounter as they serve on multiple boards.

Future research might explore the impact that diversity among board members plays in fostering the emergence of political factions that serve to restrain the power of the top management team, and, thereby, reduce the incidence of firm misbehavior. Perhaps the addition of more female and/or minority board members might change the allocation of board power. Another interesting analysis might focus on how the professional backgrounds of the board members (e.g., legal, accounting, liberal arts) might serve to alter the balance of power between the board and the top management team.

Several limitations were evident in the present study. By using the total number of investigations as reported in the firms' $10 \mathrm{~K}$ Reports, differences in the magnitude of investigations were not taken into account. Obviously, investigations involving less serious violations might be committed more often than more serious violations. While the dependent variable, "investigations," was used to measure firm misbehavior, it may be more reflective of a "sloppy" management decision framework. Even so, the responsibility for sloppy management must ultimately rest with the board. The use of a more precise measure of firm misbehavior might be considered for use in future research.

Another limitation may involve the selection for study the firm from industries within the financial services sector. We suspect that there is an industry effect here, as firms in certain industries have greater exposure to various regulations and government agency oversight. Does this increased exposure, as commonly occurs among financial services firms, result in better behavior or greater likelihood for the detection of misbehavior by regulatory agencies? Answers to these questions might be obtained by examining similar variables in firms from other industries. 
A final limitation is the use of average data over a five year time period. This obviously ignores any potential fluctuations in the variables over time. Future research may consider the effects of time. That is, perhaps there is a delay between the time in which the board takes some action and it has an effect on firm performance, both financial and social.

\section{References}

Alexander, J.A., Fennel. M. L., \& Halpern, M. T. (1993). Leadership instability in hospitals: The influence of board-CEO relations and organizational growth and decline. Administrative Science Quarterly, 38, 74-99.

Amason, A.C. \& Sapienza, H. J. (1997). The effects of top management team size and interaction norms on cognitive and affective conflict. Journal of Management, 23, 495-516.

Carroll, A.B. (1991). CSP measurement: A commentary on methods for evaluating an elusive construct. In J.E. Post (Ed.) Research in corporate social performance and policy. (pp. 385-401). Greenwich, CT: JAI Press.

Chaganti, R.S., Mahajan, V., \& Sharma, S. (1985). Corporate board size, composition and corporate failures in retailing industry. Journal of Management Studies, 22, $400-417$.

Cochran, P., Wood, W., \& Jones, T. (1985). The composition of boards of directors and incidence of golden parachutes. Academy of Management Journal, 27, 42-56.

Cohen, J. \& Cohen, P. (1983). Applied regression/correlation analysis for the behavioral sciences, (2nd ed.). Hillsdale, NJ: Lawrence Erlbaum Publishers.

Daboub, A.J., Rasheed, A. M., Priem, R. L., \& Gray, D. A. (1995). Top management team characteristics and corporate illegal activity. Academy of Management Review, 20, 138-170.

Dailey, C. M. \& Dalton, D. R. (1992). The relationship between governance structure and corporate performance in entrepreneurial firms. Journal of Business Venturing, 7, 375-386.

Dailey, C. M. \& Dalton, D. R. (1993). Board of directors leadership and structure: Control and performance implications. Entrepreneurship Theory and Practice, 17, 65-81.

Dalton, D. R., Todor, W., Spendolini, M., Fielding,, G., \& Porter, L. (1980). Organizational structure and performance: A critical review. Academy of Management Review, $5,49-64$. 
Dalton, D. R., Daily, C. M., Ellstrand, A. E., \& Johnson, J. L. (1998). Meta-analytic reviews of board composition, leadership structure, and financial performance. Strategic Management Journal, 19, 269-290.

Dalton, D. R., Daily, C. M., Johnson, J. L., \& Ellstrand, A. E. (1999). Number of directors and financial performance: A meta-analysis. Academy of Management Journal, 42, 674-686.

Dalton, D. R. \& Kesner, I. F. (1983). The effect of board composition on CEO succession and organizational performance. Quarterly Journal of Business and Economics, 42, $3-20$

Eisenhardt, K. M. \& Schoonhoven, C. B. (1990). Organizational growth: Linking founding team, strategy, environment, and growth among U.S. semiconductor ventures, 1978-1988. Administrative Science Quarterly, 35, 504-529.

Finkelstein, L. M. \& Hambrick, D. C. (1990). Top management team tenure and organizational outcomes: The moderating role of managerial discretion. Administrative Science Quarterly, 35, 484-503.

Firstenberg, P. B. \& Malkiel, B. G. (1994). The twenty-first century boardroom: Who will be in charge. Sloan Management Review, 36, 27-35.

Freeman, R. E. (1984). Strategic management: A stakeholder approach. Boston: Pitman.

Goodstein, J., Gautam, K., \& Boeker, W. (1994). The effects of board size and diversity on strategic change. Strategic Management Journal, 15, 241-250.

Griffin, J. J. \& Mahon, J. F. (1997). The corporate social performance and corporate financial performance debate: Twenty-five years of incomparable results. Business \& Society, 36, 5-31.

Hambrick, D. C. \& Fukutomi, G. D. S. (1991). The seasons of a CEO's tenure. Academy of Management Review, 16, 719-742.

Hambrick, D. C. \& Mason, P. A. (1984). Upper echelons: The organization as a reflection of its top managers. Academy of Management Review, 9, 193-206.

Heidrick \& Struggles, Inc. (1979-1986). The changing board. Chicago: Heidrick \& Struggles.

Johnson, J. L., Daily, C. M., \& Ellstrand, A. E. (1996). Boards of directors: A review and research agenda. Journal of Management, 22, 409-438.

Johnson, R. A. \& Greening, D. W. (1999). The effects of corporate governance and institutional ownership types on corporate social performance. Academy of Management Journal, 42, 564-576. 
Judge, W.Q, Jr. (1994). Correlates of organizational effectiveness: A multilevel analysis of a multidimensional outcome. Journal of Business Ethics, 13, 1-10.

Katz, R. (1982). The effects of group longevity on project communication and performance. Administrative Science Quarterly, 27, 81-104.

Kesner, I. F. \& Johnson, R. B. (1990). An investigation of the relationship between board composition and stockholder suits. Strategic Management Journal, 11, 327-336.

Kesner, I. F., Victor, B., \& Lamont, B. T. (1986). Board composition and the commission of illegal acts: An investigation of Fortune 500 companies. Academy of Management Journal, 29, 789-799.

Kidwell, R. E. \& Bennett, N. (1993). Employee propensity to withhold effort: A conceptual model to intersect three avenues of research. Academy of Management Review: $18,429-456$.

Kimberly, J. S. (1976). Organizational size and the structuralist perspective: A review, critique, and proposal. Administrative Science Quarterly, 21, 571-597.

Lau, D. C. \& Murnighan, J. K. (1998). Demographic diversity and faultines: The compositional dynamics of organizational groups. Academy of ManagementReview, $23,325-340$.

Lipton, M. \& Lorsch, J. W. (1992). A modest proposal for improved corporate governance. Business Lawyer, 48, 59-77.

Michel, J. G. \& Hambrick, D. C. (1992). Diversification posture and top management team characteristics. Academy of Management Journal, 35, 9-37.

Mintzberg, H. (1983). Power in and around organizations. Englewood Cliffs, NJ: Prentice-Hall.

Mizruchi, M. S. \& Stearns, L. B. (1988). A longitudinal study of the formation of interlocking directorates. Administrative Science Quarferly, 33, 194-210.

Ocasio, W. (1994). Political dynamics and the circulation of power: CEO succession in U.S. industrial corporations, 1960-1990. Administrative Science Quarterly, 39, 285-312.

Pearce, J. A. \& Zahra, S. A. (1992). Board composition from a strategic contingency perspective. Journal of Management Studies, 29, 411-438.

Pfeffer, J. \& Salancik, G. R. (1978). The external control of organizations: A resourcedependence perspective. New York: Harper \& Row.

Preston, L. \& Sapienza, H. J. (1990). Stakeholder management and corporate performance. Journal of Behavioral Economics, 19, 361-375. 
Ryan, H. E. \& Wiggins, R. A. (2004). Who is in whose pocket? Director compensation, board independence, and barriers to effective monitoring. Journal of Financial Economics, 73, 497-524.

Simerly, R. L. (1995). Institutional ownership, corporate social performance, and firms' financial performance. Psychological Reports, 77, 515-525.

Sonnefeld, J. (2004). Good governance and the misleading myths of bad metrics. Academy of Management Executive, 18, 108-113.

Spicer, B. H. (1978). Investors, corporate social performance and information disclosure: An empirical study. The Accounting Review, 53, 94-111.

Stanwick, P. A. \& Stanwick, S. D. (1998). The relationship between corporate social performance and organizational size, financial performance, and environmental performance: An empirical examination. Journal of Business Ethics, 17, 195- 204.

Staw, B. M. \& Ross, J. (1980). Commitment in an experimenting society: A study of the attribution of leadership from administrative scenarios. Journal of Applied Psychology, 65, 249-260.

Stearns, L. B. \& Mizruchi, M. S. (1993). Board composition and corporate financing: The impact of financial institution representation on borrowing. Academy of Management Journal, 36, 603-618.

Vafeas, M. (2003). Length of board tenure and outside director independence. Journal of Business Finance and Accounting, 30, 1043-1064.

Vance, S. C. (1983). Corporate leadership, boards, directors, and strategy. New York: McGraw-Hill.

Wang, J. \& Dewhirst, D. H. (1992). Board of directors and stakeholder orientation. Journal of Business Ethics. II, 115-124.

Weirsema, M. F. \& Bantel, K. (1992). Top management team demography and corporate strategic change. Academy of Management Journal, 35, 91-121.

Werner, S. B. (1992). The movement for reforming American business ethics: A twentyyear perspective. Journal of Business Ethics, 11, 61-70.

Wheelen, T. L. \& Hunger, J. D. (2004). Strategic management and business policy. (9th ed.). Upper Saddle River, NJ: Prentice-Hall.

Wood, D. (1991a). Corporate social performance revisited. Academy of Management Review, 16, 691-718.

Wood, D. (1991b). Social issues in management: Theory and research in corporate social performance. Journal of Management, 17, 383-406. 
Zahra, S. A. \& Pearce, J. A. (1989). Boards of directors and corporate financial performance: A review and integrative model. Journal of Management, 15, 291-334.

Dr. Mel E. Schnake, D.B.A. (Mississippi State University) is Professor of Management in the Langdale College of Business at Valdosta State University. Dr. Schnake's research has appeared in numerous journals including Journal of Management, Journal of Applied Psychology, Human Relations, Personnel Psychology, and Journal of Occupational and Organizational Psychology. Dr. Schnake's research interests include organizational citizenship behavior, organizational misconduct, work motivation and leadership.

Dr. William B. Fredenberger, Ph.D. (University of Georgia) is Professor of Management Information Systems in the Langdale College of Business at Valdosta State University. Dr. Fredenberger's research has appeared in such journals as Journal of Management Information Systems, Journal of Business Forecasting, Journal of Applied Business Research, and American Business Review. Dr. Fredenberger's research interests include corporate governance, business turnarounds, organizational change, and instructional improvement.

Dr. Robert J. Williams, Ph.D. (Florida State University) is Associate Professor of Management in the Langdale College of Business at Valdosta State University, Valdosta, Georgia. Dr. Williams' research has appeared in such journals as Academy of Management Journal, Human Relations, Journal of Business Research, Journal of Managerial Issues, and Journal of Business Strategies. Dr. Williams' research interests include top management teams, corporate governance, and business ethics. 
